UDC [639.3.043:639.211]-021.4 DOI: https://doi.org/

\title{
(i)
}

ONAFT ONAT

Open Access

B. Iegorov, Doctor of Science, Professor, E-mail: bogdanegoroff58@gmail.com https://orcid.org/0000-0001-7526-0315, ResearcherID: Q-1365-2015

Scopus Author ID: 56578802600

L. Fihurska, PhD, Associate Professor, E-mail: fihurska@gmail.com https://orcid.org/0000-0002-5555-6888, ResearcherID: C-5633-2016

O. G. Tsiundyk, PhD, Senior Lecturer, E-mail: malik2008ts@gmail.com https://orcid.org/0000-0003-1846-3110, ResearcherID: C-1401-2016

Y.V. Morozovska, Master degree student, E-mail: ymorozovska22@gmail.com Odessa National Academy of Food Technologies Odessa, Kanatna Str., Ukraine, 65039, +380487124113

\section{CONDITION AND PROSPECTS OF DEVELOPMENT OF COMPOUND FEED PRODUCTION FOR SALMONIDAE}

\begin{abstract}
The article considers the benefits of growing salmon fish in ponds, pools, cages, as well as in lakes and reservoirs in comparison with natural conditions. The main countries producing salmon fish in the world are analyzed. The share in gross production in the world is about $48 \%$, and in Ukraine is about $7 \%$. The quality and nutritional value of salmon fish is confirmed by the high market price.

The main countries producing salmon fish in the world are analyzed. The share in gross production in the world is about $48 \%$, and in Ukraine it is about $7 \%$. The quality and nutritional value of salmon fish is confirmed by the high market price.

The relevance of salmon fish breeding is substantiated, it allows for a relatively short period of time (up to 2 years) to obtain fish with a market weight of up to $3.0 \mathrm{~kg}$ The state of salmon cultivation in Ukraine is considered, about 1,500 tons of salmon are marketed annually.

The need for the production of compound feeds for salmon fish in relation to natural feed is substantiated. Compound feed expenses per $1 \mathrm{~kg}$ of salmon fish mass increase in relation to wild fish feed expenses are presented. The need for salmon fishes for nutrients and biologically active substances for the manufacture of nutritious compound feeds, due to the production of high quality salmon, is presented.

The types of compound feeds, their advantages and saving of feeding are presented. Technological methods for the production of compound feeds for salmon fish are analyzed, such as dry or wet granulation, extrusion, briquetting, compound feed production by knurling, microencapsulation of granules and paste-like compound feeds. Ready-made feed should be balanced, waterresistant, have reduced fragility, feed costs for fish growth should be minimal and have increased fish productivity. All types of feed should be completely eaten by fish, absorbed as much as possible, not secrete dyes, not lead to liver obesity, provide fish with a balanced amount of nutritious and biologically active substances. The state of domestic feed mills for the production of high-quality feed for salmon fish is analyzed. Because of it, in order to the advent of new recipes and methods of feeding, the technology for the production of animal feed for these fish species is being improved.
\end{abstract}

Key words: fish farming, salmon fish, compound feed, method of manufacture, types of compound feed.

\section{Introduction}

Fish is a source of unsaturated fatty acids, which improve metabolism, help eliminate excess cholesterol. The need for fish consumption is primarily in the high content of complete animal protein, which contains a set of amino acids in the optimal ratio [1]. Currently, fishing in the seas and oceans is the main source of fish products for the population. But the possibilities of the oceans are declining, therefore, aquaculture is actively developing, that is, fish farming under controlled conditions using advanced technologies. In a number of countries, the volume of farmed fish approaches the volume caught from natural reservoirs, and sometimes even exceeds it $[2]$.

Among the various forms of fish farming, industrial has the greatest potential for rapidly increasing production volumes. The success of this form of fish farming largely depends on the balance and quality of the feed. Therefore, in recent years, the world has been actively developing the fish feed production [2]. Salmonidae are one of the most common aquaculture objects in the world (Table 1), their share in gross production is about $48 \%$, and in Ukraine - about $7 \%$. Therefore, a significant portion of salmon is supplied to
Table 1 - The main salmon fish producing countries in the world, thousand tons

\begin{tabular}{||l||c||c||c|}
\hline \hline \multicolumn{1}{|c||}{ Country } & 2016 & 2017 & 2018 \\
\hline \hline Norway & 1171.1 & 1207.8 & 1285.5 \\
\hline \hline Chile & 504.4 & 579.1 & 607.3 \\
\hline \hline Scotland & 157.4 & 174.3 & 156.4 \\
\hline \hline North America & 168.5 & 161.7 & 167.5 \\
\hline \hline Farers Islands & 77.3 & 80.3 & 76.5 \\
\hline \hline Australia & 50.9 & 61.0 & 59.5 \\
\hline \hline Ireland & 15.8 & 17.2 & 17.8 \\
\hline \hline Island & 8.1 & 11.9 & 18.0 \\
\hline \hline Others & 12.5 & 12.1 & 14.6 \\
\hline \hline Together & 2166 & 2305.4 & 2403.1 \\
\hline \hline
\end{tabular}

Ukraine from abroad [3].

According to the recommendations of the World Health Organization, a person should consume at least 20 $\mathrm{kg}$ of fish annually. Today, fish consumption in Ukraine is $12 \ldots 14 \mathrm{~kg}$ per person. Therefore, artificial reproduction of fish currently plays an important role not only in preserving and increasing fish stocks, but also provides \section{$\square$ 西}


an improvement in the structure of biocenoses and a more rational use of the productive capacities of water bodies, which is why it is one of the levers of managed fisheries $[1,4,5]$.

Currently, the economy is based on fish farming in ponds, pools, cages, as well as in lakes and reservoirs. The objects of industrial cultivation are many species of fish, among which the main place is occupied by salmon. In Ukraine, salmon breeding is mainly represented by rainbow trout, its cultivation volume is $50 \ldots 55 \%$ of the total fish production. The largest trout farms are located in Volyn, Chernivtsi and Transcarpathian regions. According to statistics, Ukraine's fish farms have produced 20.2 thousand tons of marketable fish, including: cyprinids -9.6 thousand tons, herbivorous -7.8 thousand tons, catfish -0.2 thousand tons, sturgeons - 0.1 thousand tons, salmon -0.3 thousand tons, other species -2.2 thousand tons in 2018. Salmon farming in Ukraine is represented mainly by the cultivation of rainbow trout. Traditionally, trout production is carried out in the Western regions, in the mountains. The most famous trout farms of the enterprise are LLC SPC "Forel" (Volyn Region), "Ishkhan" Federal District (Chernivtsi Region), "Blue Field Niva" (Transcarpathian Region), CJSC "Transcarpathian Fish Plant"(Transcarpathian Region), LLC "Trion " (Rivne region), LLC "Cascade" (Volyn region), FH "Galitsky source" (Lviv region).

Salmon farming in Ukraine is based on the peculiarities of the existence of this fish: low water temperature, high flow rate and water quality. Today in Ukraine about 1500 tons of salmon fish are grown annually. In this regard, there is a need for the production of animal feed specifically for this type of fish [6].

Breeding salmon fish allows for a relatively short period of time (10 ... 24 months) to receive gourmet products with a market weight of 0.3 to $3.0 \mathrm{~kg}$. The value of food products of salmon fish is also recognized in Ukraine, which is confirmed by the high market price for this fish [7]. In the structure of world production of compound feeds, fish compound feeds account for about 3\% [1]. Salmon production in Ukraine is fully based on the use of imported feed, therefore, the development of domestic recipes is relevant and will expand the production of this type of fish.

\section{The purpose and tasks of the study}

The purpose of the study is to find information about the feasibility and economic attractiveness of salmon fisheries, the need for production and types of feed for this type of fish, the status of feed mills, and their ability to produce fish feeds.

\section{Results and Discussion}

The prerequisite for the effective cultivation of full-fledged commercial fish in industrial fish farming is the use of high-quality balanced feed. Especially sensitive to poor-quality feeds are such valuable fish species as salmon. The significance of the problem of feeding fish as one of the main ways to intensify the fish breeding process is also related to the fact that artificial feeding is a completely controllable factor: formulation, form of feed, method of manufacture and distribution of feed, determining its productive qualities.
The range of feeding salmon fish in natural conditions is quite wide and includes zooplankton, larvae of various insects. Also, the diet of this species includes mollusks and small fish. In order to produce about $450 \mathrm{~g}$ of salmon, more than $1300 \mathrm{~g}$ of wild fish are needed. With this expenditure of feed, the cost of output is greatly increased. Therefore, when growing salmon fish in artificially constructed ponds, the main one is the use of various types of feed mixtures and animal feed [8].

Compound feed costs for salmon fish are: for young people (weighing up to $3.0 \mathrm{~g}$ ) per $1 \mathrm{~kg}$ of weight gain $1.8 \mathrm{~kg}$, for fish up to 1 year old is $2.0 \ldots 2.5$, for a two-year-old - $3.0 \ldots 3.5$, for three-year-olds - $4.0 \ldots 4.5$ $\mathrm{kg}$.

Aqua feed produced in the world is intended mainly for feeding carp (32\%), shrimp (21\%), sturgeon $(12 \%)$ and salmon (12\%) (Fig. 1).

The countries of Asia and Pacific Ocean is the leaders in world fish feed production (Figure 2).

The production of artificial compound feeds for salmon fish is becoming more and more basic in modern fish farming, since feeding fish in industrial aquaculture is an essential technological element. The quality of compound feeds, as well as their composition, features of the feeding technology significantly affect the survival of the fish during the rearing period, growth rate, weight and general physiological state [9].

The digestive activity of salmon fish is affected by the quality of the feed, the amount of nutrients and biologically active substances in the feed that stimulate growth. Compound feeds and feed mixtures for growing groups of Salmonids of different ages are subject to mandatory introduction of fish oil and vegetable oils in an amount of $11 \ldots 23 \%$. With an increase in fat in feed in the amount of $7 \ldots 16 \%$, the weight of fish and the fat content in tissues increase, and with the introduction of more than $24 \%$, the indicated indicators decrease [10, $11]$.

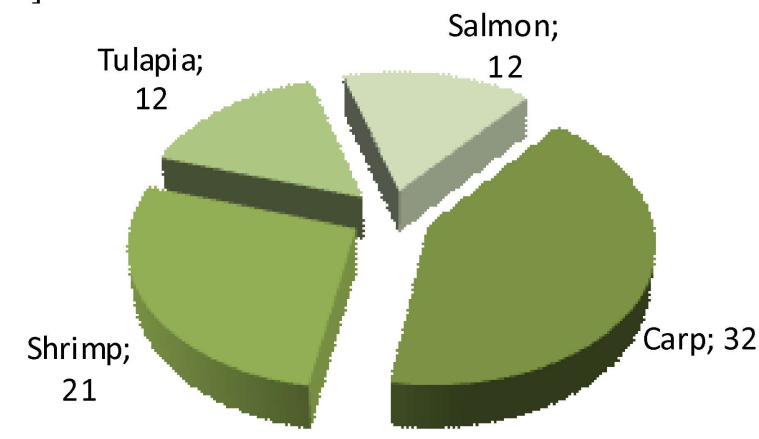

Fig. 1 - Structure of production of feed for aquaculture

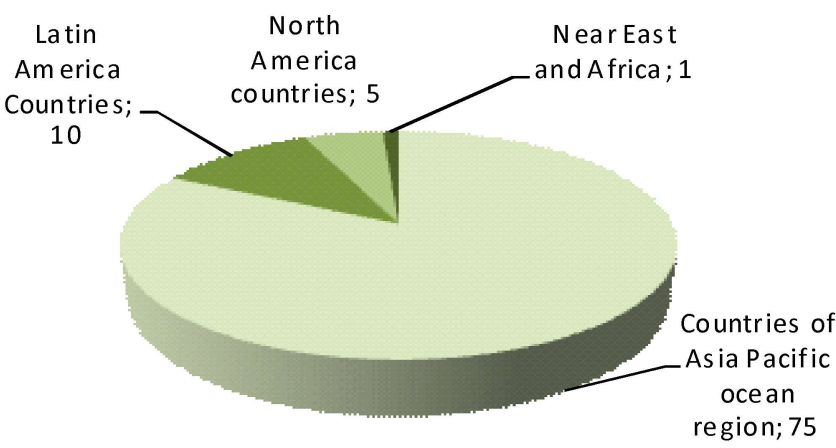

Fig. 2 - The world fish feed production by regions 
For normal life and activity of digestive enzymes, feed mixtures should contain fat and water-soluble vitamins, which are introduced in the form of vitamin premixes, since digestibility, absorption of nutrients and the activity of digestive enzymes are significantly reduced when any vitamin is deficient in the body.

Obtaining high fish productivity and economical consumption of artificial feed, as well as ensuring normal life during the cultivation of salmon fish of different age groups, is associated with knowledge of the needs of its nutrient and biologically active substances [10, 11].

The required nutrient requirements for feed for growing salmon species of different ages (Table 2) should be considered for each substance separately by species and age groups of fish, as well as in combination and ratio with natural food, animal feed and minerals [10, $11]$.

The amount of feed intake depends on the intensity of nutrient metabolism, feed nutrition, age and biological characteristics of salmon fish. The need to feed the fish depends on age and size. With age, the need for feed decreases in relation to its mass. The need for the amount of feed depends on its nutritional value, the more useful and has enough energy, the less fish needs it. The main factors that influence the need for fish feed and metabolic rate are the physicochemical factors of the aquatic environment. One of them is the temperature of the water and the content of dissolved oxygen in the water $[10,11]$.

Therefore, the main task of improving compound feed formulations is, first of all, the rapid growth, prevention and prevention of various diseases, as well as the development of immunity of salmon fish. The market of compound feeds for fish is rich in various types of compound feeds: granular, extruded, briquetted, made by knurling, microencapsulation and pasty compound feeds. Granular feed is obtained in two ways: dry or wet. Dry granulation takes place in a granulator press at a vapor pressure in the range of $0.3 \ldots 0.4 \mathrm{MPa}$ and a temperature of $110 \ldots 120{ }^{\circ} \mathrm{C}$. To obtain granular grains, the granules are crushed to sizes depending on the weight of the fish (Table 3). One of the significant drawbacks of granulation by the dry method is that the granules are not waterproof, have increased fragility and, when they enter the water, swell quickly [12].

Wet pelleting process occurs during the previous wetting of bulk feed, thus increasing the bulk density and density of the product. Granulation takes place in the same way as in the dry method. After exiting the matrix, the pellets are sent for drying on a calorifer dryer. Drying is carried out at a temperature of $100 \ldots 110^{\circ} \mathrm{C}$. The pellets are dried quickly, and heating does not lead to the destruction of nutrients. Compared to pelleted feed produced by the dry method, the saving of compound feeds when growing fish is $18 \ldots 21 \%$. The fragility of the pellets does not exceed $2 \%$, while the dry method is up to $10 \%$. The water resistance of granular feed does not exceed four hours [12].

Extruded feed is made on special equipment - in extruders, by forcing the feed mixture through steam

Table 3 - The size of the grains and granules of dry granular compound feeds depending on the mass of Salmon fish

\begin{tabular}{||l||c|c||}
\hline \multirow{2}{*}{\multicolumn{1}{|c||}{ Fish weight, $\mathrm{g}$}} & \multicolumn{2}{c||}{ Size, $\mathrm{mm}$} \\
\cline { 2 - 3 } & crumbles & pellets \\
\hline \hline up to 0,2 & $0.4 \ldots 0.6$ & - \\
\hline \hline $0.2 \ldots 1.0$ & $0.6 \ldots 1.0$ & - \\
\hline \hline $1.0 \ldots 2.0$ & $1.0 \ldots 1.5$ & - \\
\hline \hline $2.0 \ldots 5.0$ & $1.5 \ldots 2.5$ & - \\
\hline \hline $5.0 \ldots 15.0$ & - & 3.2 \\
\hline \hline $15.0 \ldots 50.0$ & - & 4.5 \\
\hline \hline $50.0 \ldots 200.0$ & - & 6.0 \\
\hline \hline 200.0 and more & - & 8.0 \\
\hline \hline
\end{tabular}

through forming holes. Feed made in this way has a porous internal texture. As a result of the influence of pressure and temperature in the processed material, complete feed sterilization occurs. The particles of extruded compound feeds are more durable than the fractions of granular compound feeds, because the fragility and screening of this type of feed is less than $1 \%$. When using extruded compound feeds, the amount of dust entering the water when feeding fish is reduced by $75 \%$, and water pollution is reduced. In addition, the extruded compound feed does not soak within 24 hours in water. Extruded feed is more effectively absorbed by fish, and when using it, low feed ratios can be obtained. For example, when growing rainbow trout on extruded compound feeds, one can obtain feed coefficients in the range of $0.6 \ldots 0.8$, while on granular compound feeds the lower border of feed coefficients is $1.2 \ldots 1.4[8,12]$.

The technological process of briquetting consists in preliminary moistening of loose feed, pressing and cooling. The difference from the granulation process is the type of press and matrix. Feeding salmon fishes with briquetted compound feeds showed that the savings of feed compared to feed of dry granulation is $12 \%$, and compared with pasty - $18 \%$ [10].

The production of compound feeds by the knurling method consists in the fact that loose feed is premoistened and fed into a disk granulator for rolling compound feed in the form of balls. Using this method, it is possible to obtain granules with a diameter of $3 \ldots 35 \mathrm{~mm}$ with different strengths, which is achieved by changing the slope, side height and speed of rotation of the plate. Feed saving when feeding them to salmon fish compared to dry granulation granules is up to $6 \%$, and with pasty -

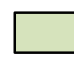


up to $12 \%$. The water resistance of the ball granules of feed is $10 \ldots 24$ hours, they swell more than 2:00. The disadvantage of this method is that the components of the feed recipe must be brought to a fine grinding and granules during knurling at the same time get different sizes, so the severity of sorting and drying [10].

The microencapsulation of the granules consists in the application to the surface of the finished compound feed waterproof coating, which is formed with the help of film-forming substances in the fluidized state. Receive spherical pellets from fine feed. The size of the product obtained depends on the size of the droplets of the liquid being sprayed. The advantages of microencapsulation are minimal feed loss when feeding fish, high water resistance of granules (more than $3 \mathrm{~h}$ ) and swelling time in water $(10 \ldots 20 \mathrm{~min})$ [13].

The technological process for the production of paste-like compound feeds consists in adding loose feed to the mixer, chopped green mass, water or an aqueous solution of microadditives. The moisture content of the finished paste is $45 \ldots 50 \%$. Lack of pasty compound feeds: poor water resistance (losses due to leaching of nutrients can reach $50 \%$ ), the introduction of connecting substances is recommended [13].

All types of feed should be completely eaten by Salmon fish, absorbed by them as much as possible, do not secrete dyes, do not lead to fatty liver, do not give an additional load on the excretory system of fish, provide fish with a balanced amount of proteins, carbohydrates, fats, macro- and micronutrients, and have immune stimulating property, contain a sufficient amount of carotenoids to maintain a bright color of the fish.

Most domestic feed mills focus on products for warm-blooded farm animals that do not require strong grinding of feed raw materials; almost all enterprises use outdated steam granulation technology. These technologies are not suitable for salmon species of fish, in accordance with high-protein feed, today not all feed mills can produce.

Therefore, in Ukraine, industrial fish farming is based mainly on imported compound feeds. Because of the advent of new recipes and feeding methods, old feed mills are reconstructed and new small enterprises for the production of compound feeds for fish, including salmon, equipped with modern equipment, appear.

\section{Conclusion}

Thus, the salmon farming business is attractive for investors because of the relatively short period of time for obtaining products with a marketable weight of up to $3.0 \mathrm{~kg}$, as well as the high nutritional value of fish. In the article it was given the needs of salmon in nutrients, as well as size of pellets. The technological processes of fish feed production were given. Analysis of the state of production of compound feeds for fish in Ukraine shows the need for the development of modern recipes that take into account the physiological needs of salmon fish. It is necessary to improve and optimize the production technology of compound feeds for salmon fish, which will lead to stabilization of their quality, cost reduction and increased competitiveness of compound feeds on the market. It is also necessary to develop new technologies for the production of animal feed for salmon fish, which will reduce the dependence on imported animal feed.

\section{REFERENCES}

1. Kachnyy O.S. Stan i tendentsiyi rozvytku svitovoho rybnoho hospodarstva $i$ yoho rol' u prodovol'chomu zabezpechenni naselennya // Ekonomika APK. 2009. №12. S. 11-15.

2. Aheets V.YU., Koshak ZH.V., Koshak A.É. Problemy y perspektyvy proyzvodstva byolohychesky polnotsennykh kombykormov dlya ryb v respublyke Belarus' // Vesty Natsyonal'noy Akademyy nauk Belarusy. Seryya ahrarnykh nauk. 2017. №2. S. 91-99.

3. Ibatullin I. I. ta in. Aktual'ni problemy normovanoyi hodivli koropovykh ta lososevykh ryb // Naukovyy visnyk Natsional'noho universytetu bioresursiv $i$ pryrodokorystuvannya Ukrayiny. Ser.: Tekhnolohiya vyrobnytstva $i$ pererobky produktsiyi tvarynnytstva. 2012. Vyp. 179. S. 143-149.

4. Brug C., Ridler N. Global aquaculture qutlook in the next decades: analysis of national aquaculture production forecasts to 2030 // FAO Fisheries Circular. 2004. № 1001, Rome, FAO. 47 p.

5. Bureau D., Hua K., Young Cho C. Effect of feeding level on growth and nutrient deposition in rainbow trout (Oncorhynchus mykissWalbaum) growing from 150 to $600 \mathrm{~g}$. Aquaculture research. 2006. Vol. 37, p. 1090-1098

6. De v Ukrayini vyroshchuyut' veslonosa ta inshi ekzotychni vydy ryb // Vsi novyny: [Veb-sayt]. Kyyiv, 2018. URL: https://agrigator.com.ua/2018/11/09/de-v-ukraini-viroshhujut-veslonosa-ta-inshi-ekzotichni-vidi-rib-agronews-ual (data zvernennya: $01.02 .2020)$

7. Shumova V.M., Mendryshora P.D. Osoblyvosti nakopychennya masy u ts'oholitok $i$ dvolitok rayduzhnoyi foreli // Visnyk ahrarnoyi nauky. 2017. №5. S. 63-67.

8. Korma dlya ryby: sovremennye reshenyya // Rybnaya Sfera. 2015. № 2 (13). S. 6-14.

9. Saryev B.T., Tumenov A.N., Absatyrov H.H., dr. Rybovodno-byolohycheskye pokazately vyrashchyvanyya molody shypa pry kormlenyy kormom s dobavlenyem probyotykov // Vestnyk nauky Kazakhskoho ahrotekhnycheskoho unyversyteta ym. S. Seyfullyna (mezhdystsyplynarnyy). 2017. №2 (93). S. 75-79.

10. Andryushchenko A.I., Vovk N.I. Akvakul'tura shtuchnykh vodoym. Chastyna II. Industrial'na akvakul'tura: pidruchnyk. Kyyiv, 2014. $586 \mathrm{~s}$.

11. Kal'chenko E.Y. Opyt yspol'zovanyya razlychnykh typov kormov pry vyrashchyvanyy molody lososey na rybovodnykh zavodakh // Yssledovanyya vodnykh byolohycheskykh resursov Kamchatky y severo-zapadnoy chasty Tykhoho okeana. 2009. Vyp. 12. S. 7279 .

12. Yehorov B.V., Fihurs'ka L.V. Analiz tekhnolohichnykh sposobiv vyrobnytstva kombikormiv dlya ryb // Zernovi produkty $i$ kombikormy. 2012. № 1 (45). S. 35-42.

13. Yehorov B.V., Fihurs'ka L.V. Osoblyvosti vyrobnytstva kombikormiv dlya ryb // Khranenye y pererabotka zerna. 2015. №11-12 (197). S. $45-47$ 
Б.В. Сгоров, д-р техн. наук, професор, E-mail: bogdanegoroff58@gmail.com https://orcid.org/0000-0001-7526-0315, ResearcherID: Q-1365-2015, Scopus Author ID: 56578802600

Л.В. Фігурська, канд. техн. наук, доцент, E-mail: fihurska@gmail.com https://orcid.org/0000-0002-5555-6888, ResearcherID: C-5633-2016

О.Г. Цюндик, канд. техн. наук, ст. викладач, E-mail: malik2008ts@gmail.com https://orcid.org/0000-0003-1846-3110, ResearcherID: C-1401-2016 Я.В. Морозовська, магістр, E-mail: ymorozovska22@gmail.com Одеська національна академія харчових технологій, вул. Канатна, 112, Одеса, 65039, Україна, +380487124113

\title{
СТАН ТА ПЕРСПЕКТИВИ РОЗВИТКУ ВИРОБНИЦТВА КОМБІКОРМІВ ДЛЯ ЛОСОСЕВИХ РИБ
}

\begin{abstract}
Анотація
У статті розглянута користь вирощування лососевих риб в ставках, басейнах, садках, а також в озерах $і$ водосховищах в порівняні з природними умовами.

Проаналізовано основні країни-виробники лососевих риб у світі. Частка у валовому виробництві у світі становить близько $48 \%$ а в Украӥні - близько 7 \%. Якість та харчова цінність лососевих риб підтверджується високою ринковою иіною.

Обтрунтовано актуальність розведення лососевих риб, щя дозволяє за відносно незначний проміжок часу (до 2 років) отримувати рибу товарною масою до 3,0 кг. Розглянуто стан вирощування лососевих в Украӥні, щзороку вирощують близько 1500 тонн товарних лососевих риб.

Обтрунтовано необхідність виробництва комбікормів для лососевих риб по відношенню до природного корму. Представлено витрати комбікормів на 1 кг приросту маси лососевих риб по відношенню до витрат годівлі дикою рибою.

Наведена потреба лососевих риб в поживних і біологічно активних речовинах для виготовлення поживних комбікормів, внаслідок отримання високоякісного лосося.

Представлені види комбікормів, їх переваги та економія годівлі. Проаналізовано технологічні способи виробництва комбікормів для лососевих риб такі, як гранулювання сухим або вологим способом, екструдування, брикетування, виготовлення комбікормів способом накатування, мікрокапсулювання гранул та пастоподібні комбікорми. Готові комбікорми повинні бути збалансовані, водостійкі, мати понижену крихкість, затрати корму на приріст риби повинні бути мінімальними та мати підвищену рибопродуктивність. Всі види кормів повинні повністю з їдатися рибами, максимально засвоюватися, не виділяти фарбувальних речовин, не призводити до ожиріння печінки, забезпечувати риб збалансованою кількістю поживними і біологічно активними речовинами.
\end{abstract}

Проаналізовано стан вітчизняних комбікормових заводів для виробничтва якісних комбікормів для лососевих риб. Завдяки появі нових рещептур і методів годівлі удосконалюється технологія виробництва комбікормів для циих видів риб.

Ключові слова: рибництво, лососеві риби, комбікорм, спосіб виготовлення, види комбікормів.

\section{ЛITEPATУРA}

1. Kachnyy O.S. Stan i tendentsiyi rozvytku svitovoho rybnoho hospodarstva i yoho rol' u prodovol'chomu zabezpechenni naselennya // Ekonomika APK. 2009. №12. S. 11-15.

2. Aheets V.YU., Koshak ZH.V., Koshak A.É. Problemy y perspektyvy proyzvodstva byolohychesky polnotsennykh kombykormov dlya ryb $v$ respublyke Belarus' // Vesty Natsyonal'noy Akademyy nauk Belarusy. Seryya ahrarnykh nauk. 2017. №2. S. 91-99.

3. Ibatullin I. I. ta in. Aktual'ni problemy normovanoyi hodivli koropovykh ta lososevykh ryb // Naukovyy visnyk Natsional'noho universytetu bioresursiv i pryrodokorystuvannya Ukrayiny. Ser.: Tekhnolohiya vyrobnytstva i pererobky produktsiyi tvarynnytstva. 2012. Vyp. 179. S. 143-149.

4. Brug C., Ridler N. Global aquaculture qutlook in the next decades: analysis of national aquaculture production forecasts to 2030 // FAO Fisheries Circular. 2004. № 1001, Rome, FAO. 47 p.

5. Bureau D., Hua K., Young Cho C. Effect of feeding level on growth and nutrient deposition in rainbow trout (Oncorhynchus mykissWalbaum) growing from 150 to $600 \mathrm{~g}$. Aquaculture research. 2006. Vol. 37, p. 1090-1098

6. De v Ukrayini vyroshchuyut' veslonosa ta inshi ekzotychni vydy ryb // Vsi novyny: [Veb-sayt]. Kyyiv, 2018. URL: https://agrigator.com.ua/2018/11/09/de-v-ukraini-viroshhujut-veslonosa-ta-inshi-ekzotichni-vidi-rib-agronews-ual (data zvernennya: 01.02.2020)

7. Shumova V.M., Mendryshora P.D. Osoblyvosti nakopychennya masy u ts'oholitok i dvolitok rayduzhnoyi foreli // Visnyk ahrarnoyi nauky. 2017. №5. S. 63-67.

8. Korma dlya ryby: sovremennye reshenyya // Rybnaya Sfera. 2015. № 2 (13). S. 6-14.

9. Saryev B.T., Tumenov A.N., Absatyrov H.H., dr. Rybovodno-byolohycheskye pokazately vyrashchyvanyya molody shypa pry kormlenyy kormom s dobavlenyem probyotykov // Vestnyk nauky Kazakhskoho ahrotekhnycheskoho unyversyteta ym. S. Seyfullyna (mezhdystsyplynarnyy). 2017. №2 (93). S. 75-79.

10. Andryushchenko A.I., Vovk N.I. Akvakul'tura shtuchnykh vodoym. Chastyna II. Industrial'na akvakul'tura: pidruchnyk. Kyyiv, 2014. $586 s$.

11. Kal'chenko E.Y. Opyt yspol'zovanyya razlychnykh typov kormov pry vyrashchyvanyy molody lososey na rybovodnykh zavodakh // Yssledovanyya vodnykh byolohycheskykh resursov Kamchatky y severo-zapadnoy chasty Tykhoho okeana. 2009. Vyp. 12. S. 72-79.

12. Yehorov B.V., Fihurs'ka L.V. Analiz tekhnolohichnykh sposobiv vyrobnytstva kombikormiv dlya ryb // Zernovi produkty i kombikormy. 2012. № 1 (45). S. 35-42.

13. Yehorov B.V., Fihurs'ka L.V. Osoblyvosti vyrobnytstva kombikormiv dlya ryb // Khranenye y pererabotka zerna. 2015. №11-12 (197). S. 45-47.

Received 09.01.2020

Reviewed 05.02.2020

Revised 26.02.2020 Approved 03.03.2020

Cite as Vancouver Citation Style

Yegorov B., Fihurska L., Tsiundyk O., Morozovska Y. Condition and prospects of development of compound feed production for salmonidae. Grain Products and Mixed Fodder's, 2020; 20 (1, 77): 31-35. DOI:

Cite as State Standard of Ukraine 8302:2015

Condition and prospects of development of compound feed production for salmonidae / Yegorov B. et al. // Grain Products and Mixed Fodder's. 2020. Vol. 20, Issue 1 (77). P. 31-35. DOI: 